\title{
Biological Control of Anthracnose (Colletotrichum gloeosporioides) in Pepper and Cherry Tomato by Streptomyces sp. A1022
}

\author{
Hyi Jin Kim ${ }^{1}$, Eun Jung Lee ${ }^{2}$, Sung Hyo Park ${ }^{1}$, Hoi-Seon Lee ${ }^{3} \&$ Namhyun Chung ${ }^{1}$ \\ ${ }^{1}$ Department of Biosystems and Bitechnology, College of Life Sciences and Biotechnology, Korea University, \\ Seoul, Korea \\ ${ }^{2}$ Haegangbio Co. Ltd., Yeoju-gun, Korea \\ ${ }^{3}$ College of Agriculture and Life Science, Chonbuk National University, Jeonju, Korea \\ Correspondence: Namhyun Chung, Department of Biosystems and Bitechnology, College of Life Sciences and \\ Biotechnology, Korea University, Seoul, Korea. Tel: 82-2-3290-3026. E-mail: nchung@korea.ac.kr \\ Hoi-Seon Lee, College of Agriculture and Life Science, Chonbuk National University, Jeonju 561-756, Korea. \\ Tel: 82-63-270-2544. E-mail: hoiseon@jbnu.ac.kr
}

Received: November 12, 2013 Accepted: December 2, 2013 Online Published: January 15, 2014

doi:10.5539/jas.v6n2p54 URL: http://dx.doi.org/10.5539/jas.v6n2p54

\begin{abstract}
This study sought to develop a biological control agent against plant diseases of various crops and vegetables using Streptomyces sp. A1022. We found that the culture broth had an inhibitory effect against several fungal pathogens, including Colletotrichum gloeosporioides, Phytophthora capsici, Pyricularia grisea, and Cercospora canescens. The antifungal activity of the culture broth was stable $(>93 \%)$ across a broad range of temperatures $\left(25-90{ }^{\circ} \mathrm{C}\right)$ and $\mathrm{pH}$ ( $\mathrm{pH} 2-9$ ), suggesting that the solid concentrate (SC) of strain A1022 might be effective against a broad range of fungal pathogens. We examined the inhibitory efficacy of this strain against anthracnose by Colletotrichum gloeosporioides in infections of pepper and cherry tomato. We found the degree of anthracnose injury to pepper to be in the following order: untreated control $\approx$ eugenol (sopra extract) $>$ tebuconazol (a chemical fungicide) $>$ azoxystrobin (a chemical fungicide) $\approx$ strain A1022 SC. Strain A1022 SC also had an inhibitory effect against anthracnose on cherry tomato. In a field test, azoxystrobin (10,000 ppm active ingredient; 1,000 -fold dilution) and strain A1022 SC $\left(2 \times 10^{4}\right.$ colony forming unit $\mathrm{mL}^{-1} ; 500$-fold dilution) had inhibitory effects of 68.0 and $61.6 \%$ against pepper anthracnose, respectively. Our results suggest that strain A1022 SC can be an alternative to chemical fungicides, at least for pepper and cherry tomato anthracnose infections caused by C. gloeosporioides.
\end{abstract}

Keywords: anthracnose, biocontrol, Colletotrichum gloeosporioides, pepper, cherry tomato, Streptomyces

\section{Introduction}

Fungal phytopathogens are one of the most serious problems in commercial crops (Pohanka, 2006). Soilborne diseases such as gray mold, late blight, and anthracnose are major sources of crop loss, and these diseases repeatedly damage a variety of fruits and vegetables including tomatoes, strawberries and peppers. Pepper (Capsicum annuиm L.), an important crop cultivated worldwide, can suffer large losses in both yield and quality due to anthracnose (Pakdeevaraporn et al., 2005). Anthracnose is caused by at least five fungi, e.g., Colletotrichum gloeosporioides, which is the dominant and most virulent fungal species causing pepper anthracnose (Kim et al., 2004).

Though chemical fungicides have been extensively used worldwide to control various pathogens, their use has many attendant problems, such as environmental pollution, deteriorating human health, development of pathogen resistance to fungicides, and phytotoxicity (Dubey et al., 2008). To minimize these problems, researchers have sought to develop biological control agents for soilborne plant pathogens that might be more environment- friendly. Phytopathogens have been used to control several antagonistic microorganisms, including Bacillus spp. (Ongena \& Jacques, 2008), Streptomyces spp. (Bressan, 2003), Pseudomonas spp. (Hubbard et al., 1983), and Trichoderma spp. (Sivan \& Chet, 1986). As it has been reported, the inhibitory mechanisms of antagonistic microorganisms are antibiosis, competition, parasitism, and predation (Lockwood, 1988; Handelsman \& Stabb, 1996).

Streptomyces species have antifungal activity and are broadly used as biological control agents to control soilborne diseases. Synthetic fungicides have often been replaced with biofungicides using Streptomyces sp. to control 
pathogens (Errakhi et al., 2007; Hassan et al., 2011). Beyer \& Diekmann (1985) reported that cell wall degradation of Penicillium chrysogenum occurred due to the chitinase system of extracellular protein from Streptomyces sp. ATCC11238. More recently, the biological control effect of Streptomyces padanus IA70-5 was evaluated in the laboratory against the pepper anthracnose caused by Colletotrichum acutatum (Chi et al., 2012).

Previously, we have suggested Streptomyces sp. A1022 as a potential biological control agent (Lee et al., 2012; Lee et al., 2011). In this study, we aimed to prove the antifungal activity of solid concentrate of Streptomyces sp. A1022 toward anthracnose of pepper and cherry tomato under green house and field condition. We compared its antifungal activity with other commercial fungicides.

\section{Method}

\subsection{Growth of Microorganisms}

Streptomyces sp. A1022 was isolated from soil gathered in Gangwon Province, Korea (Lee et al., 2011). Strain A1022 was then cultured in an ISP2 medium containing $\left(\mathrm{g} \mathrm{L}^{-1}\right)$ glucose 5 , yeast extract 5 , malt extract 10 , in an Erlenmeyer flask $\left(150 \mathrm{rpm}, 28.5^{\circ} \mathrm{C}\right)$ for seven days. The phytopathogenic fungi [(Colletotrichum gloeosporioides (ATCC16330), Phytophthora capsici (ATCC46746), Pyricularia grisea (ATCC MYA-2403), Cercospora canescens (ATCC 11919), Fusarium oxysporum f.sp. lycopersici (ATCC 46933), Alternaria mali (ATCC42096))] were incubated at $28^{\circ} \mathrm{C}$ for seven days on a potato dextrose agar (PDA; BD Difco, NJ, USA) before use.

\subsection{Antifungal Activity Test}

The culture broth of Streptomyces sp. A1022 was centrifuged at $5,000 \times \mathrm{g}$ at $4{ }^{\circ} \mathrm{C}$ for $20 \mathrm{~min}$ and then the mycelium and supernatant were separated using filtration through Whatman No. 2 paper. The mycelium from $1 \mathrm{~L}$ culture broth was then extracted with the same amount of methanol for $24 \mathrm{~h}$, while the supernatant from $1 \mathrm{~L}$ culture broth was extracted with the same amount of hexane and ethyl acetate for $24 \mathrm{~h}$. Antifungal activity was estimated by a disk diffusion assay against $C$. gloeosporicides. The fungi spores $\left(1 \times 10^{6}\right.$ spores $\left.\mathrm{mL}^{-1}\right)$ were spread on a PDA plate, and then a paper disk containing the fungal culture extract via methanol, hexane, or ethyl acetate $(30 \mu \mathrm{L})$ was placed on the plate. After $20 \mathrm{~h}$ at $28.5^{\circ} \mathrm{C}$, diameters of inhibition zones were measured.

In order to evaluate the range of the control spectrum, six fungal pathogens, as mentioned above, were tested by the disk diffusion method. Spores $\left(1 \times 10^{6}\right.$ spores $\left.\mathrm{mL}^{-1}\right)$ of each of the six fungal pathogens were spread on PDA plates. Methanol extract $(30 \mu \mathrm{L})$ was added to a paper disk, which was then put on the plate. Diameters of inhibition zones were measured as above.

\subsection{Effect of Temperature and $p H$ on Antifungal Activity}

For the temperature stability test, the culture broth was exposed to $25,60,70,80,90$, and $121^{\circ} \mathrm{C}$ for $15 \mathrm{~min}$. For the $\mathrm{pH}$ stability test, the culture broth was adjusted to $\mathrm{pH} 2,4,9$, and 12 . The antifungal activity following exposure to various temperatures and $\mathrm{pH}$ conditions was estimated by the disk diffusion assay. Diameters of inhibition zones were measured as above.

\subsection{Formulation of Streptomyces sp. A1022}

Streptomyces sp. A1022 was formulated as solid concentrate (SC) to maintain stability and preserve the antifungal components. First, strain A1022 was grown in medium containing $\left(\mathrm{g} \mathrm{L}^{-1}\right)$ glucose 34 , soya flour 7.5, yeast extract $3, \mathrm{CaCO}_{3} 0.25$, and $\mathrm{MgSO}_{4} \cdot 7 \mathrm{H}_{2} \mathrm{O} 0.25$. The culture was agitated at $150 \mathrm{rpm}$, aeration of $0.3 \mathrm{vvm}$ for $82 \mathrm{~h}$ using a $500 \mathrm{~L}$ fermenter. The resulting culture broth was then processed as described previously (Lee et al., 2012).

\subsection{Effect of Application Interval of Streptomyces sp. A1022 SC on Inhibitory Efficacy to Pepper Anthracnose}

To evaluate the inhibitory efficacy of Streptomyces sp. A1022 SC against pepper anthracnose, a pot assay was performed in a greenhouse. For this pot assay, azoxystrobin ( $20 \%$ solid concentrate, Syngenta Korea, Seoul, Korea) was diluted 2,000 fold with tap water (10,000 ppm active ingredient), and strain A1022 SC $\left(1 \times 10^{7}\right.$ colony forming unit $\left.\mathrm{mL}^{-1}\right)$ was diluted 1,000 fold with tap water $\left(1 \times 10^{4}\right.$ colony forming unit $\left.\mathrm{mL}^{-1}\right)$. The pots (diameter $12 \mathrm{~cm} \times$ height $14 \mathrm{~cm}$ ) were filled with a silt laom soil (sand: silt: clay= $8.3 \%: 61.5 \%: 20.2 \%$; organic carbon, $3.51 \%$, pH 6.2 , field capacity, 30). Fungi spores of C. gloeosporioides were adjusted to $1 \times 10^{6}$ spores $\mathrm{mL}^{-1}$, and after artificial inoculation, a spray of strain A1022 SC diluents was applied three times on pepper seedlings (Hot pepper Londari 35, Asia Seed Co. Ltd., Seoul, Korea) at intervals of 5 and 7 days. A total of 15 pots were employed, for three trials of five pots. Statistical analyses were performed using SPSS version 20.0 for Windows (SPSS Inc., IL, USA). 


\subsection{Comparison of Inhibitory Efficacy of Strain A1022 SC with Other Fungicides}

The biological control effect of strain A1022 SC against anthracnose caused by C. gloeosporioides was compared with that of the commercial fungicides azoxystrobin, tebuconazole $(12 \%$ wettable power, Hanearl Science, Taebaek, Korea), and eugenol (0.5\% sophora extract, solid concentrate, Nanpong Shenyu Green Medicine Co., Nanpong, China). Azoxystrobin and tebuconazole were diluted 1,000 fold with tap water $(20,000 \mathrm{ppm}$ active ingredient and 12,000 ppm, respectively), and eugenol and strain A1022 SC were both diluted 500 fold with tap water $\left(1,000 \mathrm{ppm}\right.$ active ingredient and $2 \times 10^{4}$ colony forming unit $\left.\mathrm{mL}^{-1}\right)$. Pepper fruits $(>10 \mathrm{~cm}$ in length) were sterilized by swabbing with $70 \%$ ethanol and $1 \%$ sodium hypochloride to remove pre-existing pathogens or other microorganisms, and fruits were then punched using a sterilized hole puncher. Then, $50 \mu \mathrm{L}$ of $C$. gloeosporioides spores $\left(1 \times 10^{6}\right.$ spores $\left.\mathrm{mL}^{-1}\right)$ were inoculated onto a paper disk, and the disk was placed on the hole of pepper fruits. The treated peppers were then incubated in a growth chamber for $24 \mathrm{~h}$ at $28{ }^{\circ} \mathrm{C}$ with a $75 \%$ relative humidity. After one day, $50 \mu \mathrm{L}$ of each test fungicide was applied to a fruit (triplicate), placing one material on the paper disk to which C. gloeosporioides had been applied earlier. The inoculated peppers were checked for 7 and 12 days and held in the growth chamber at $28{ }^{\circ} \mathrm{C}$ and $75 \%$ relative humidity.

\subsection{Biological Control Efficacy of Strain A1022 SC Toward Cherry Tomato Anthracnose}

Cherry tomatoes (Tomato Berry King F1 Hybrid, Thompson \& Morgan, Suffolk, UK) were washed and sterilized with $70 \%$ ethanol and $1 \%$ sodium hypochloride to eliminate other pathogens, and then punched using a sterilized hole puncher. Paper disks were inoculated with $50 \mu$ l of a solution of $C$. gloeosporioides spores $\left(1 \times 10^{6}\right.$ spores $\left.\mathrm{mL}^{-1}\right)$ and then the paper disks were placed over the holes on the cherry tomatoes. Treated cherry tomatoes were held in a growth chamber for $24 \mathrm{~h}$ at $28{ }^{\circ} \mathrm{C}$ and $75 \%$ relative humidity, after which a 1,000 fold dilution of strain A1022 SC $(50 \mu \mathrm{L})$ was added to the paper disk. The cherry tomatoes were incubated and observed in the growth chamber for 7 days at $28{ }^{\circ} \mathrm{C}$ and $75 \%$ relative humidity.

\subsection{Monitoring Effect of Strain A1022 SC Against Anthracnose Under Field Conditions}

Field experiments were conducted from July 20, 2011 to August 10, 2011 in Chungju City, Chungbuk, Korea, where anthracnose by $C$. gloeosporioides is prevalent during pepper cultivation. The planted area for the experiments was approximately $160 \mathrm{~m}^{2}$. A 500 fold dilution of strain A1022 SC and a 1,000 fold dilution of azoxystrobin were sprayed on the stems and leaves of pepper plants ( $>15 \mathrm{~cm}$ in height, Hot pepper Londari 35) until the solution ran off the plant surface. Applications were made on July 20, July 27, and August 3 . The percentage of disease incidence and rate of disease inhibition in each treatment was recorded on August 10, 2011. All statistical analyses were carried out using SPSS version 20.0 for Windows (SPSS Inc., Chicago, IL, USA).

\section{Results}

\subsection{Antifungal Activity of Streptomyces sp. A1022}

We found that the methanol extract of Streptomyces sp. A1022 from mycelium suppressed the growth of $C$. gloeosporioides, giving a $39.0 \pm 0.5 \mathrm{~mm}$ inhibition zone in the disk diffusion assay (Figure 1). The hexane and ethyl acetate extracts from supernatant also had suppressive effects against $C$. gloeosporioides, but the sizes of the inhibition zones they caused (hexane: $35.1 \pm 0.6 \mathrm{~mm}$; ethyl acetate: $34.2 \pm 0.8 \mathrm{~mm}$ ) were smaller than that of the methanol extract (Figure 1). The pure solvents had no effect on pathogen growth in vitro, suggesting that both mycelium and supernatant had antifungal activity.

Using the methanol extract, the antifungal activity of Streptomyces sp. A1022 was investigated against three additional fungal pathogens ( $P$. capsici, F. oxysporum f.sp. lycopersici, and A. mali), including three fungal pathogens (C. gloeosporioides, $P$. grisea, and C. canescens) from our previous study as reference (Lee et al., 2011). The extract had antifungal activity against four of these six fungal pathogens: $C$. gloeosporioides (anthracnose), $P$. capsici (blight and fruit rot fungus), $P$. grisea (rice blast fungus), and $C$. canescens (leaf spot and blight fungus). Thus, one additional fungal pathogen, $P$. capsici, was added to the list of six phytopathogenic fungi which could be suppressed by Streptomyces sp. A1022. The size of the inhibition zones in the disk diffusion assay was larger for $C$. gloeosporioides $(39.0 \pm 0.5 \mathrm{~mm})$ and $P$. grisea $(43.9 \pm 0.6 \mathrm{~mm})$ than for $P$. capsici $(13.0 \pm 0.5 \mathrm{~mm})$ or for $C$. canescens $(19.2 \pm 0.6 \mathrm{~mm}$ ) (Figure 2). Therefore, the methanol extract of mycelium would likely be effective toward not only C. gloeosporioides but also six other fungal pathogens tested. 


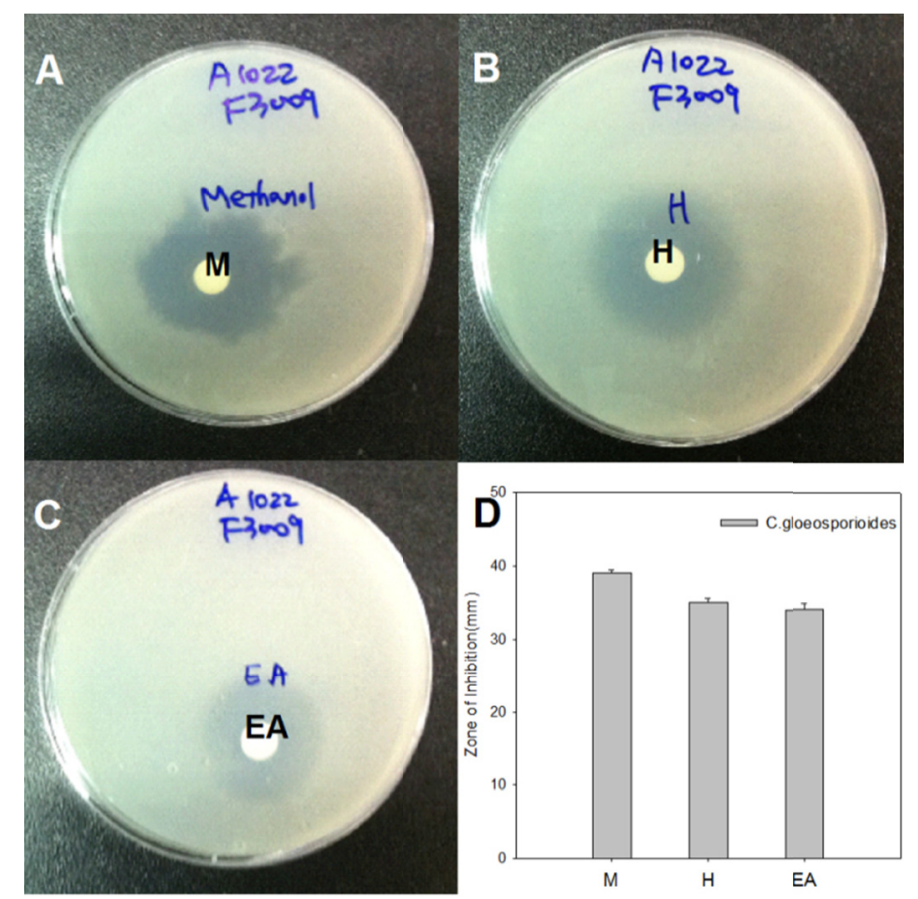

Figure 1. Antifungal activity of strain A1022 against anthracnose caused by Colletotrichum gloeosporioides as determined by disk diffusion assay. (A) $\mathrm{M}$ : methanol extract, (B) $\mathrm{H}$ : hexane extract, (C) EA : ethyl acetate extract, (D) The size of inhibition zone with each extract. Data represent the mean $\pm \mathrm{SD}(\mathrm{n}=3)$

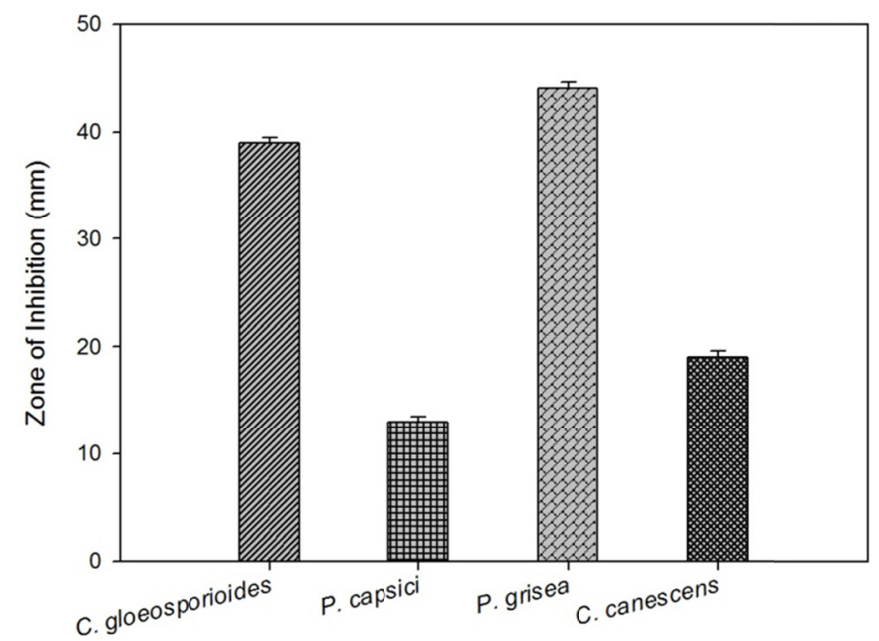

Figure 2. Antifungal activity of methanol extract against various fungal pathogens as determined by disk diffusion assay. The size of inhibition zone was shown with each fungal pathogen.

Data represent the mean $\pm \mathrm{SD}(\mathrm{n}=3)$

\subsection{Thermal and pH Stability of Streptomyces sp. A1022 Culture Broth}

The culture broth of Streptomyces sp. A1022 was exposed to various temperatures for $15 \mathrm{~min}$, and the remaining activity measured. The antifungal activity of heat-treated culture broth against $C$. gloeosporioides was highest at $60{ }^{\circ} \mathrm{C}(100 \%)$, and more than $90 \%$ of the activity was maintained at $25,70,80$, and $90^{\circ} \mathrm{C}$. At $121^{\circ} \mathrm{C}$, only $72 \pm 2.3 \%$ of activity remained (Table 1). Meanwhile, the $\mathrm{pH}$ of the culture broth was adjusted to 2, 4, 9 and 12 and the residual activity was then measured by disk diffusion assay. The antifungal activity of $\mathrm{pH}$-adjusted culture broth against $C$. gloeosporioides was highest at $\mathrm{pH} 9(100 \%)$, and more than $90 \%$ of the activity was maintained at $\mathrm{pH} 2$ and 4 . At $\mathrm{pH} 12$, only $63 \pm 3.2 \%$ of activity remained. Thus, the antifungal activity of the culture broth of strain A1022 was stable across a wide range of temperature and $\mathrm{pH}$, except $121^{\circ} \mathrm{C}$ and $\mathrm{pH} 12$ (Table 2). 
Table 1. Antifungal activity of heat-treated culture broth of Streptomyces sp. A1022 against Colletotrichum gloeosporioides

\begin{tabular}{cc}
\hline Temperature $\left({ }^{\circ} \mathrm{C}\right)$ & Relative remaining activity $(\%)$ \\
\hline 25 & $94.8 \pm 2.9$ \\
60 & 100 \\
70 & $98.3 \pm 3.7$ \\
80 & $96.6 \pm 4.5$ \\
90 & $93.1 \pm 3.1$ \\
$121^{*}$ & $72 \pm 2.3$ \\
\hline
\end{tabular}

The culture broth of Streptomyces sp. A1022 was exposed to various temperatures for 15 min. Residual activities against Colletotrichum gloeosporioides were measured as relative to the activity of $60{ }^{\circ} \mathrm{C}$.

*Autoclaved at $121^{\circ} \mathrm{C}$ for $15 \mathrm{~min}$.

Table 2. Antifungal activity of culture broth of Streptomyces sp. A1022 against Colletotrichum gloeosporioides at various $\mathrm{pHs}$

\begin{tabular}{cc}
\hline $\mathrm{pH}^{*}$ & Relative remaining activity (\%) \\
\hline 2 & $93.0 \pm 2.9$ \\
4 & $94.7 \pm 3.5$ \\
9 & 100 \\
12 & $63.2 \pm 3.2$
\end{tabular}

${ }^{*} \mathrm{pH}$ of the culture broth was adjusted, and residual activities against Colletotrichum gloeosporioides were measured as relative to the activity at $\mathrm{pH} 9$.

\subsection{Effect of Application Interval of Streptomyces sp. A1022 SC on Inhibitory Efficacy of Pepper Anthracnose}

For the controls, the average disease incidence was more than $15 \%$. Two materials, a 1,000 fold dilution of strain sp. A1022 SC $\left(1 \times 10^{4}\right.$ colony forming unit $\left.\mathrm{mL}^{-1}\right)$ and a 2,000 fold dilution of azoxystrobin $(10,000 \mathrm{ppm}$ active ingredient), were used to investigate application intervals using a pot assay (Table 3 ). The average disease incidence at 5 days after inoculation was lower than at 7 days. In addition, the inhibition rates at both 5 and 7 days post inoculation were at least $10 \%$ higher with strain A1022 SC than with azoxystrobin.

Table 3. Effect of application interval of Streptomyces sp. A1022 SC and azoxystrobin on inhibitory efficacy of pepper anthracnose*

\begin{tabular}{cccc}
\hline Application interval (day) & Treatment & Disease incidence (\%)Inhibition rate (\%) \\
\hline & azoxystrobin & $10.5 \pm 2.7$ & \multirow{2}{*}{$42.5 \pm 4.4$} \\
& $(10,000$ ppm active ingredient $)$ & $p=0.061 \ddagger$ & \\
strain A1022 SC & $8.0 \pm 1.9$ & $56.2 \pm 0.8$ \\
& $\left(1 \times 10^{4}\right.$ colony forming unit $\left.\mathrm{mL}^{-1}\right)$ & $p=0.033$ & - \\
\hline & Untreated & $18.3 \pm 4.1$ & $40.8 \pm 28.0$ \\
7 & azoxystrobin & $11.5 \pm 5.3$ & \\
& $(10,000$ ppm active ingredient $)$ & $p=0.08$ & $55.5 \pm 2.3$ \\
& strain A1022 SC & $9.4 \pm 5.1$ & - \\
& $\left(1 \times 10^{4}\right.$ colony forming unit $\left.\mathrm{mL}^{-1}\right)$ & $p=0.04$ & \\
& Untreated & $19.5 \pm 2.8$ &
\end{tabular}

*Streptomyces sp. A1022 SC was sprayed on pepper seedling after artificial inoculation of Colletotrichum gloeosporioides. Each agent was tested in triplicate. Data represent the mean $\pm \mathrm{SD}(\mathrm{n}=3)$.

†Disease inhibition rate $(\%)=($ Untreated-Treated $) /$ Untreated $\times 100$.

$\ddagger$ Probability against the values of disease incidence of untreated. 


\subsection{Comparison of Inhibitory Efficacy Toward Pepper Anthracnose Among Antifungal Agents}

Pepper fruits were inoculated using paper disks sprayed with the fungicides azoxystrobin and tebuconazole, the plant extract eugenol, or strain A1022 SC. When each treated pepper was observed after 7 days, similar rates of inhibition of pepper anthracnose were observed for azoxystrobin, tebuconazole, and strain A1022 solid concentrate (SC) (Figure 3A). However, the inhibitory efficacy was much weaker with eugenol than with the other antifungal agents. After 12 days, the pepper treated with strain A1022 SC and azoxystrobin showed a slight deterioration, while the peppers treated with tebuconazole and eugenol were very significantly deteriorated, as was the untreated control (Figure 3B). The degree of pepper damage by anthracnose after 7 days decreased in the following order: untreated control $\approx 500$ fold dilution of eugenol $(1,000 \mathrm{ppm}$ active ingredient $)>1,000$ fold dilution of tebuconazole (12,000 ppm active ingredient) $>1,000$ fold dilution of azoxystrobin $(20,000 \mathrm{ppm}$ active ingredient $) \approx 500$ fold dilution of strain A1022 SC $\left(2 \times 10^{4}\right.$ colony forming unit $\left.\mathrm{mL}^{-1}\right)$. After 12 days, the overall degree of pepper damage increased but remained almost in the same order (not shown).
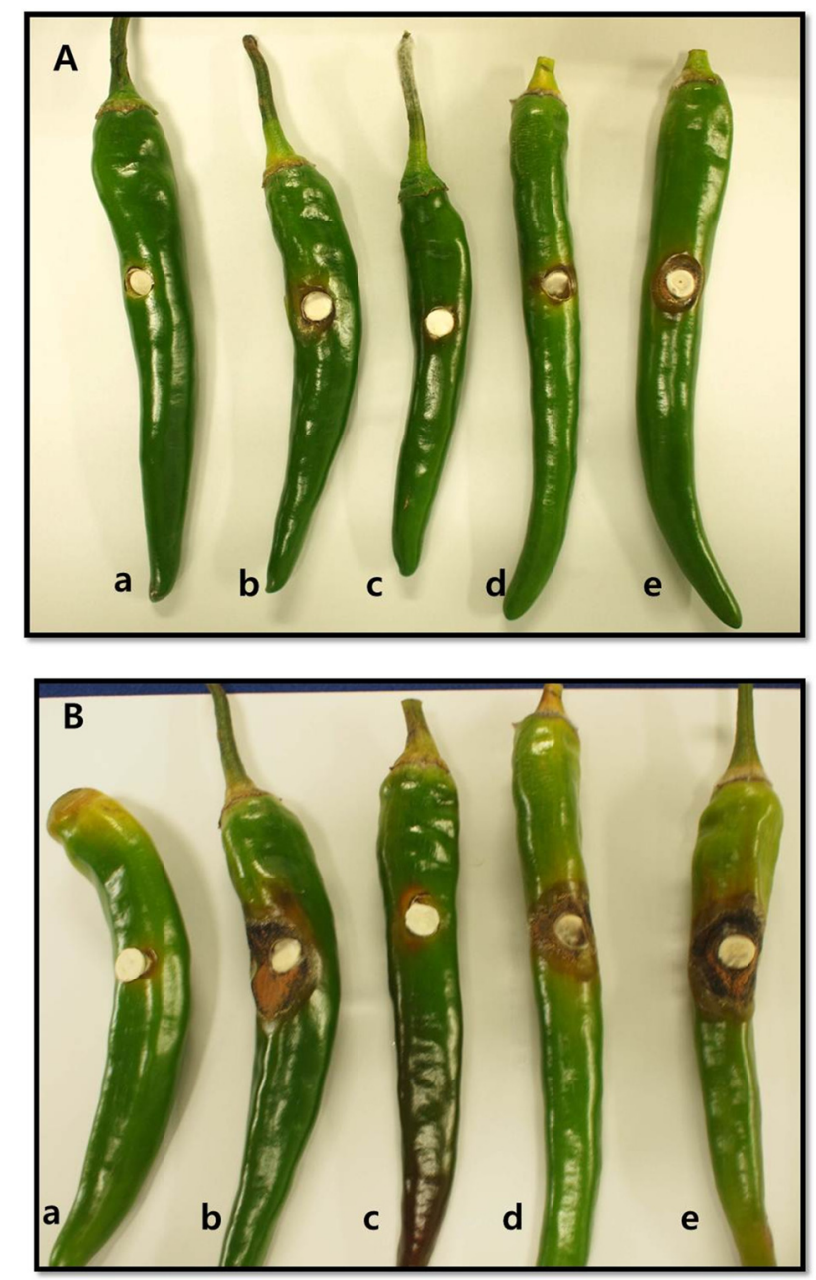

Figure 3. Comparison of inhibitory efficacy with various antifungal agents including Streptomyces sp. A1022 SC after (A) 7 and (B) 12 days. Peppers were treated with each antifungal agent and checked after 7 and 12 days. (a) 500 fold dilution of strain A1022 SC $\left(2 \times 10^{4}\right.$ colony forming unit $\left.\mathrm{mL}^{-1}\right)$, (b) untreated, (c) 1,000 fold dilution of azoxystrobin (20,000 ppm active ingredient), (d) 1,000 fold dilution of tebuconazole (12,000 ppm active ingredient), (e) 500 fold dilution of eugenol (1,000 ppm active ingredient)

\subsection{Inhibitory Efficacy of Streptomyces sp. A1022 SC Against Cherry Tomato Anthracnose}

A 1,000 fold dilution of strain A1022 SC was employed to estimate its inhibitory efficacy of anthracnose in cherry tomatoes. Cherry tomatoes were artificially inoculated with $C$. gloeosporioides and then treated with a 1,000 fold dilution $\left(1 \times 10^{4}\right.$ colony forming unit $\left.\mathrm{mL}^{-1}\right)$ of strain A1022 SC. The cherry tomatoes were observed for 7 days, and 
those cherry tomatoes treated with strain A1022 SC had almost no symptoms of anthracnose, while those with no treatment were damaged by the growth of anthracnose, suggesting that strain A1022 SC had biological control efficacy in cherry tomato as well as pepper (Figure 4).

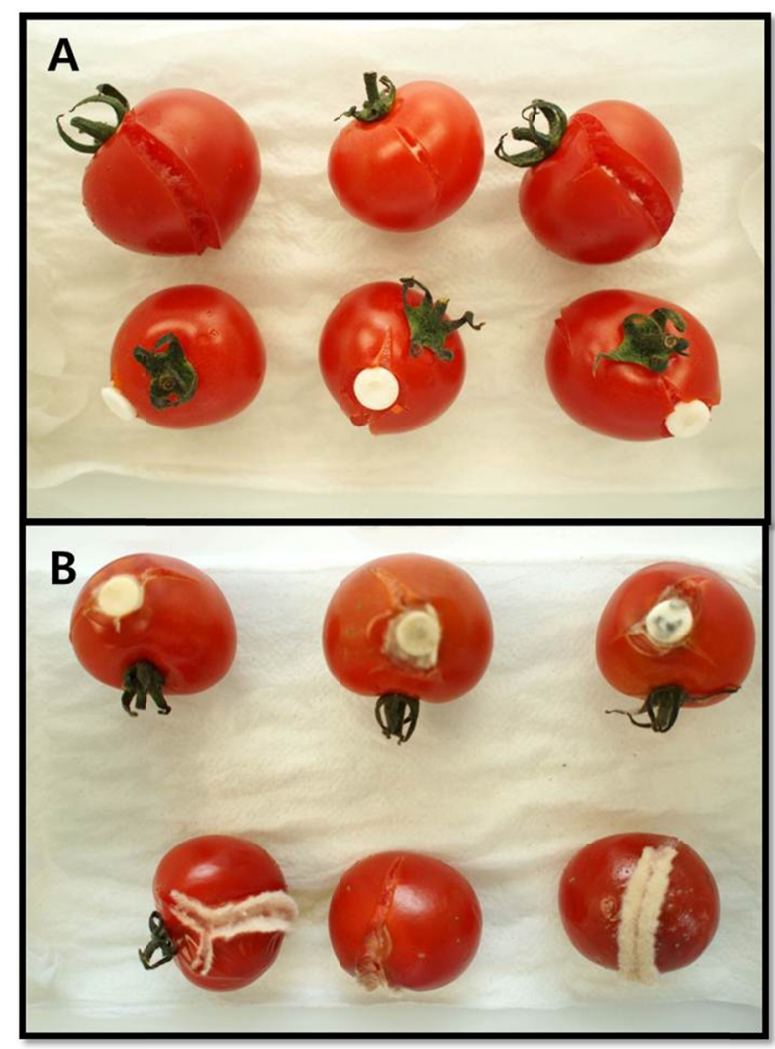

Figure 4. Inhibitory effect of Streptomyces sp. A1022 SC against cherry tomato anthracnose after 7 days. Cherry tomatoes were treated with each antifungal agent and checked after 7 days. (A) 1,000 fold dilution of strain A1022 SC. (B) Untreated

\subsection{Inhibitory Efficacy of Streptomyces sp. A1022 SC Under Field Conditions}

Table 4. Inhibition rate of pepper anthracnose by Streptomyces sp. A1022 SC and azoxystrobin under field conditions*

\begin{tabular}{ccc}
\hline Treatment & Disease incidence $(\%)$ & Inhibition rate $(\%)^{\dagger}$ \\
\hline azoxystrobin & $13.3 \pm 0.6(p=0.001 \mp)$ & $68.0 \pm 2.3$ \\
$(20,000$ ppm active ingredient $)$ & & \\
$\begin{array}{c}\text { Streptomyces } \text { sp. A1022 SC } \\
\left(2 \times 10^{4} \text { colony forming unit } \mathrm{mL}^{-1}\right)\end{array}$ & $16.0 \pm 1.0(p<0.001)$ & $61.6 \pm 4.2$ \\
Untreated & $41.7 \pm 2.1$ & - \\
\hline
\end{tabular}

*1,000 fold dilution of azoxystrobin (20,000 ppm active ingredient) and 500 fold dilution of strain A1022 SC $\left(2 \times 10^{4}\right.$ colony forming unit $\left.\mathrm{mL}^{-1}\right)$ were sprayed on pepper three times. The field was monitored after 7 days from treatment date (July 20 and 27, 2011, and August 8, 2011), and final check was performed in 2011.8.10. Data represent the mean $\pm \mathrm{SD}(\mathrm{n}=3)$.

tDisease inhibition rate $(\%)=($ Untreated-Treated $) /$ Untreated $\times 100$,

$\ddagger$ Probability against the values of disease incidence of untreated. 
As shown in the results above and in our previous study (Lee et al., 2012), the inhibitory efficacy of strain A1022 SC is almost equal to that of azoxystrobin. To determine if this inhibitory efficacy of strain A1022 SC works well under field conditions, a field experiment was undertaken using a 1,000 fold dilution of azoxystrobin $(10,000 \mathrm{ppm}$ active ingredient) and a 500 fold dilution of strain A1022 SC $\left(2 \times 10^{4}\right.$ colony forming unit $\left.\mathrm{mL}^{-1}\right)$. The percentage of inhibition rate for strain A1022 SC was 61.6\%, about 6.4\% lower than that for azoxystrobin (Table 4), suggesting that while its efficacy might be a little lower than that of the chemical fungicide, strain A1022 SC can still be considered an efficient agent for pepper anthracnose treatment.

\section{Discussion}

Interest in the development of ecologically friendly biological control agents is increasing, in part because antifungal substances produce fewer lasting harmful residues and the risk of fungicide resistance is lower (Wilhelm, 1973; Lima et al., 2006). In this study, a novel strain of Streptomyces sp., A1022, was evaluated as a biological control agent against pepper and cherry tomato anthracnose caused by $C$. gloeosporioides. The activity found in the culture broth of strain A1022 had broad thermal and pH stability. As these characteristics could make both the formulation process and distribution of the antifungal substance easier, the culture broth of strain A1022 was formulated as a solid concentrate (SC) for easy use and availability.

Commercially, it is desirable if antifungal agents control several fungal pathogens. The methanol extract of strain A1022 had a strong antifungal activity toward anthracnose fungus, rice blast fungus, leaf spot and blight fungus, and blight and fruit rot fungus, tobacco brown spot fungus (Alternaria logipes), melanose fungus (Diaporthe citri), and sclerotial fungus (Sclerotinia soleroforum) based on our present and previous results (Lee et al., 2011). Previously, various Streptomyces species have been reported as having excellent suppressive effect on various phytopathogens. For example, banana anthracnose caused by Colletitrichum musae was controlled by Streptomyces sp. SRM1 (Taechowisan et al., 2009), Streptomyces sp. PM5 inhibited blast and sheath blight diseases of rice (Tae, 1998), and Streptomyces padanus TH-04 showed strong antifungal activity against Monilinia fructicola (Lim et al., 2007). However, those Streptomyces sp. are often effective toward only a few fungal phytopathogens. We suspect that the strain A1022 SC has a broad anthracnose inhibitory efficacy to various phytopathogens of many crops and vegetables.

The strain tested had a high disease inhibitory efficacy in both cherry tomatoes and peppers. In addition, it had almost as high a disease inhibitory efficacy against $C$. gloeosporioides under field condition as under greenhouse conditions, making it a promising candidate for the control of anthracnose in a variety of crops and over a range of conditions.

\section{Acknowledgments}

This work was supported by the Ministry for Food, Agriculture, and Fisheries research funds (Grant no. 1090733).

\section{References}

Beyer, M., \& Diekmann, H. (1985). The chitinase system of Streptomyces sp. ATCC 11238 and its significance for fungal cell wall degradation. Applied Microbiology and Biotechnology, 23, 140-146. http://dx.doi.org/10.1007/BF01982731

Bressan, W. (2003). Biological control of maize seed pathogenic fungi by use of actinomycetes. Biocontrol, 48(2), 233-240. http://dx.doi.org/10.1023/A:1022673226324

Chi, T. T. P., Choi, O., Kwak, Y. S., Son, D., Lee, J. J., \& Kim, J. (2012). Evaluation of Streptomyces padanus IA70-5 strain to control hot pepper anthracnose (Colletotrichum acutatum). Journal Agricultural and Life Science, 46(3), 37-45.

Dubey, N., Srivastava, B., \& Kumar, A. (2008). Current status of plant products as botanical pesticides in storage pest management. Journal Biopesticide, 1(2), 182-186.

Errakhi, R., Bouteau, F., Lebrihi, A., \& Barakate, M. (2007). Evidences of biological control capacities of Streptomyces spp. against Sclerotium rolfsii responsible for damping-off disease in sugar beet (Beta vulgaris L.). World Journal of Microbiology and Biotechnology, 23(11), 1503-1509. http://dx.doi.org/10.1007/s11274-007-9394-7

Handelsman, J., \& Stabb, E. V. (1996). Biocontrol of soilborne plant pathogens. Plant Cell, 8(10), 1855-1869. http://dx.doi.org/10.1105/tpc.8.10.1855

Hassan, A. A., El-Barawy, A. M., \& El Mokhtar, M. N. (2011). Evaluation of biological compounds of Streptomyces species for control of some fungal diseases. Journal of American Science, 7(4), 752-760. 
Hubbard, J., Harman, G., \& Hadar, Y. (1983). Effect of soilborne Pseudomonas spp. on the biological control agent. Trkhoderma hamatum, on pea seeds. Ecology and Epidemiology, 73(5), 655-659.

Kim, K.-H., Yoon, J.-B., Park, H.-G, Park, E. W., \& Kim, Y. H. (2004) Structural modifications and programmed cell death of chili pepper fruit related to resistance responses to Colletotrichum $\begin{array}{llll}\text { gloeosporioides infection. } & \text { Phytopathology, } & \text { 94(12), }\end{array}$ http://dx.doi.org/10.1094/PHYTO.2004.94.12.1295

Lee, E. J., Ahn, Y. J., Lee, H. S., \& Chung, N. (2012). Biocontrol of pepper anthracnose by a new Streptomycessp. A1022 under greenhouse condition. Journal Korean Society for Applied Biological Chemistry, 55(3), 447-449. http://dx.doi.org/10.1007/s13765-012-2077-6

Lee, E. J., Hwang, K. Y., Lee, H. S., \& Chung, N. (2011). Characterization of a new Streptomyces sp. A1022 as a potential biocontrol agent. Journal Korean Society for Applied Biological Chemistry, 54(3), 488-493. http://dx.doi.org/10.3839/jksabc.2011.075

Lim, T. H., Oh, H. C., Kwon, S. Y., Kim, J. H., Seo, H. W., Lee, J. H., ... Min, B. -S. (2007). Antifungal activity of valinomycin, a cyclodepsipeptide from Streptomyces padanus TH-04. Natural Product Sciences, 13(2), 144-147.

Lima, G., De Curtis, F., Piedimonte, D., Spina, A. M., \& De Cicco, V. (2006). Integration of biocontrol yeast and thiabendazole protects stored apples from fungicide sensitive and resistant isolates of Botrytis cinerea. Postharvest Biology and Technology, 40(3), 301-307. http://dx.doi.org/10.1016/j.postharvbio.2006.01.017

Lockwood, J. L. (1988). Evolution of concepts associated with soilborne plant pathogens. Annual Review Phytopathology, 26, 93-121. http://dx.doi.org/10.1146/annurev.py.26.090188.000521

Ongena, M., \& Jacques, P. (2008). Bacillus lipopeptides: versatile weapons for plant disease biocontrol. Trends in Microbiolilogy, 16(3), 115-125. http://dx.doi.org/10.1016/j.tim.2007.12.009.

Pakdeevaraporn, P., Wasee, S., Taylor, P. W. J., \& Mongkolporn, O. (2005). Inheritance of resistance to anthracnose caused by Colletotrichum capsici in Capsicum. Plant Breeding, 124(2), 206-208. http://dx.doi.org/10.1111/j.1439-0523.2004.01065.x

Pohanka, A. (2006). Antifungal antibiotics from potential biocontrol microorganisms. Ph.D Thesis, Swedish University of Agricultural Sciences, Uppsala, Sweden.

Sivan, A., \& Chet, I. (1986). Biological control of Fusarium spp. in cotton, wheat and muskmelon by $\begin{array}{lllll}\text { Trichoderma harzianum. } & \text { Journal }\end{array}$ http://dx.doi.org/10.1111/j.1439-0434.1986.tb00892.x

Tae, K. H. (1998) Fungicidal effects of herbicides on several plant diseases and controlling effect of piperophos on rice blast caused by Pyricularia grisea. Korean Journal Plant Pathology, 14(1), 28-33.

Taechowisan, T., Chuaychot, N., Chanaphat, S., Wanbanjob, A., \& Tantiwachwutikul, P. (2009). Antagonistic effects of Streptomyces sp. SRM1 on Colletotrichum musae. Biotechnology, 8(1), 86-92. http://dx.doi.org/10.3923/biotech.2009.86.92

Wilhelm, S. (1973). Principles of biological control of soil-borne plant diseases. Soil Biology and Biochemistry, 5(6), 729-737. http://dx.doi.org/10.1016/0038-0717(73)90017-5

\section{Copyrights}

Copyright for this article is retained by the author(s), with first publication rights granted to the journal.

This is an open-access article distributed under the terms and conditions of the Creative Commons Attribution license (http://creativecommons.org/licenses/by/3.0/). 